is also "a potential means to enlarge our research mission internationally”, he says.

Jacquelline Fuller, a spokeswoman for the Gates Foundation, says that the initiative will soon embrace other partners to make it truly international in scope. To this end, the foundation is in discussions with the London School of Hygiene and Tropical Medicine, where Gates has already contributed $\$ 40$ million to a malaria research centre, and the British researchfunding charity the Wellcome Trust.

Gates sees the initiative as a starting point in tackling a huge imbalance whereby less than $10 \%$ of the $\$ 70$-billion annual world spend on medical research goes on the diseases that cause $90 \%$ of illness and death. "There is great potential for science and technology to solve persistent global health challenges, but far greater resources are needed," he says.

Existing global expenditure on malaria research is estimated to be just $\$ 100$ million annually, and the Special Programme for Research and Training in Tropical Diseases run by the United Nations and the World Bank has only $\$ 30$ million a year to cover ten major tropical diseases.

Impressive as it, the Gates grant is small beer next to the $\$ 1.5$ billion that the World Health Organization has said is needed annually to support a Global Health Research Fund dealing with major killer diseases. But Francis Nkrumah, director of the Noguchi Memorial Institute for Medical Research at the University of Ghana and the only African on the board of the new initiative, says it marks a major step towards that goal. He thinks that it will help to forge a consensus among biologists on the most promising research avenues, and hence attract further private and public research funds. "This is a beacon of hope for Africa," he says.

www.gatesfoundation.org

\title{
Transgenic crop trial's gene flow turns weeds into wimps
}

\section{David Adam, Amsterdam}

Could 'superweeds' carrying genes from genetically modified crops behave less like Superman and more like Clark Kent, his puny alter ego? The first results from a pioneering field trial in the United States suggest as much - and that the effects of gene flow from transgenic crops may be less aggressive than some environmentalists predict.

The experiment, run by Neal Stewart and his colleagues at the University of Tennessee, Knoxville, would have struggled to win regulatory approval in Europe. In it the team used an oilseed rape crop that had been given a gene from the bacterium Bacillus thuringiensis $(B t)$, enabling it to produce a toxin that repels insects. They crossed the genetically modified variety with a wild relative, Brassica rapa, then backcrossed the resulting hybrid with the wild plant again, and released the resulting 'superweed' into the environment.

The resistant weed's ability to compete as a pest - and therefore the likelihood of the rogue gene sweeping through wild plant populations - was assessed by its effect on fields of wheat. In other fields, the researchers introduced naturally occurring weeds.

The team found that the transgenic weed was far from dominant, having 20\% less effect on wheat yield than the unmodified B. rapa weeds. Stewart presented his team's results, from the first year of trials in North Carolina and Georgia, at a conference on gene flow between plants held in Amsterdam on 21-24 January.

Stewart, who believes that genetically modified crops are currently "over-regulated", suggests that the modified weeds lose potency because they are disrupted by the genetic load

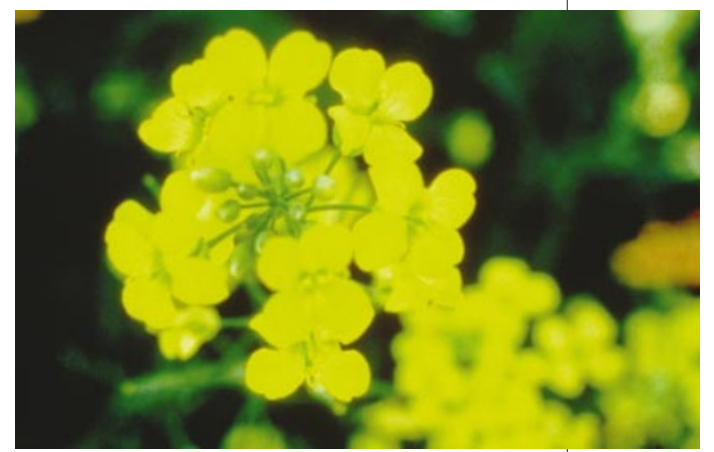

Early trial results suggest that gene flow from transgenic crops puts weeds at a disadvantage.

of crop genes being carried over with the $B t$ transgene. "Weeds have undergone years of selection that make them very good at what they do,"he says.

Other plant researchers welcomed the results as an important advance. "We need to move on from asking whether gene flow takes place, to investigating what happens when and where it does," says Brian Johnson, biotechnology adviser to the conservation group English Nature and an expert on transgenic-crop issues.

But some cautioned that the preliminary results are not a green light for the use of such crops in Europe, where their commercial planting is under a de facto moratorium. In a separate study announced last year, plant ecologist Allison Snow at Ohio State University in Columbus found that similar Bt transgenes can make wild sunflowers produce more seeds - a sign that modified wild populations could prosper and spread in the environment (see Nature 419, 655; 2002).

\section{Head of Spanish lab network quits over lack of funds}

\section{Monica Salomone, Madrid}

The president of Spain's main network of scientific research laboratories has resigned, complaining that the government gave him neither the resources nor the autonomy he needed to do the job.

Theoretical physicist Rolf Tarrach, who ran the CSIC research council for two-anda-half years, says that he will leave his post within a few weeks, once he has helped the government to select his successor.

Spanish science minister Josep Piqué confirmed the news, saying that Tarrach "had expressed his wish to go back to his research a long time ago".

At the CSIC, Tarrach was responsible for
120 laboratories, which employ about 2,200 researchers. But he often complained about the lack of funding and human resources. "I could do very little of what I intended" in the position, he says.

In a letter to the science ministry last October, Tarrach had asked to be replaced if certain measures were not taken. He wanted to see salaries for CSIC researchers rise by $7-10 \%$ to match those of university researchers. "The best researchers won't go to the CSIC" unless this happens, he says. “Decisions about the CSIC's policy that used to be taken by its presidency are now taken at the ministry," he adds. "This makes it very difficult to run a modern institution."
Tarrach says that his requests were ignored, so he filed his resignation two weeks ago and will now return to his academic post at the University of Barcelona.

The resignation has yet to be announced publicly. This, says Tarrach, is to avoid "interference" with the storm of criticism currently lashing the Spanish government over its handling of the ecological disaster caused by the sinking of the tanker Prestige (see Nature 420, 347; 2002).

One possible candidate to replace Tarrach is Emilio Lora-Tamayo, a physicist who is currently vice-president of the CSIC and head of a commission advising the government on its response to the Prestige oil spill. 